\title{
ANALISIS KOMPOSISI JENIS DAN POTENSI SIMPANAN KARBON PADA EKOSISTEM KARST DI RESORT TONDONG TALLASA TAMAN NASIONAL BANTIMURUNG BULUSARAUNG
}

\section{(Analysis Of Composition Of Types And Potential Of Carbon Deposits In Karst Ecosystem In Resort Tondong Tallasa In Bantimurung Bulusaraung National Park)}

\author{
Much Syachrir $^{1)}$, St Subaedah ${ }^{2)}$ dan Ayu K Parawansa ${ }^{2)}$ \\ ${ }^{1)}$ Taman Nasional BABUL, E-mail : chaken27@gmail.com \\ ${ }^{2)}$ Program Studi Agroteknologi, Fakultas Pertanian UMI Mkassar
}

\begin{abstract}
The purpose of this study is to identify the composition and potential of carbon deposits of karst ecosystem vegetation at the Tondong Tallasa Resort Management Division of Balocci Regional National Park I Bantimurung Bulusaraung National Park covering surface biomass (BAP). The research was conducted in April 2017 - June 2017 on the karst ecosystem in the flat area, the fault path, slope with a few stones, slopes with many rocks and hills in the Bantimurung Bulusaraung National Park. The dominant types consist of Syzygium acuminatissima and Dracontomelon dao in the flat primary forest, Kleinhovia hospital and Alstonia scholaris in the primary forest of broken paths, Pterocymbium tinctorium and Beilschmiedia gemmiflora in the primary forest slope of a few miles, Duabanga molucana and Garuga floribunda in primary forest slopes many stones, Duabanga molucana and Sterculia foetida in the primary forest of the dorsal hills. The results showed that the average mean carbon forest reserve was $56.26 \pm 9.52$ tons / ha, in the primary forest of fault paths was $44.64 \pm 8.87$ tons / ha, in the primary forests slope a slight rock of $52.12 \pm 9.84$ ton / ha, in primary forest slope of many stone of $15.39 \pm 3.06$ ton / ha, and in primary forest of hillside equal to $11.35 \pm 2.26$ ton / ha. Tree with diameter $>20 \mathrm{~cm}$ gives a significant contribution to total BAP ranging from 11.18 - 95.49 ton / ha or $43.63-84.86 \%$. While trees with diameter of 5 - $20 \mathrm{~cm}$ only ranged from $6.73-15.55$ tons / ha or $10.90-37.22 \%$.
\end{abstract}

Keywords : Biomass over the surface, carbon deposits, ecosystems karst, Bantimurung Bulusaraung National Park

\section{PENDAHULUAN}

Kawasan Taman Nasional Bantimurung Bulusaraung dibagi ke dalam tiga tipe ekosistem utama, yaitu ekosistem hutan di atas batuan karst (forest over limestone/hutan di atas batu gamping) atau lebih dikenal dengan nama ekosistem karst, ekosistem hutan pegunungan bawah serta ekosistem hutan hujan non Dipterocarpaceae pamah. Batas ketiga tipe ekosistem ini sangat jelas karena hamparan batuan karst yang berdinding terjal dengan puncak menaranya yang relatif datar, sangat berbeda dengan topografi dataran rendah yang mempunyai topografi datar sampai berbukit, serta kondisi ekosistem hutan pegunungan yang ditandai oleh bentuk relief yang terjal atau terkadang bergelombang (Darsono et al., 2008). Perubahan iklim global terjadi akibat terganggunya keseimbangan energi antara bumi dan atmosfir. Keseimbangan tersebut dipengaruhi oleh peningkatan 
suhu bumi yang terkait langsung dengan peningkatan konsentrasi gas rumah kaca (GRK). Peningkatan emisi diakibatkan oleh proses pembangunan dan industri berbahan bakar migas (BBM) yang semakin meningkat dan kegiatan penggunaan lahan serta alih guna lahan dan kehutanan (Hairiah \& Rahayu, 2007).

Solusi efektif mengatasi perubahan iklim akibat pemanasan global dapat dilakukan dengan dua aspek yaitu adaptasi dan mitigasi (CIFOR, 2009).

Hutan alami merupakan penyerap dan penyimpan karbon (C) tertinggi bila dibandingkan dengan sistem penggunaan lahan lainnya, dikarenakan keragaman pohonnya yang tinggi, kerapatan tumbuhan bawah, dan serasah di permukaan tanah yang banyak. Salah satu peranan Taman Nasional (TN) Bantimurung Bulusaraung dalam konteks perubahan iklim adalah sebagai penyerap dan penyimpan karbon yaitu vegetasi hidup di dalam hutan melalui proses fotosintesis mampu menyerap gas $\mathrm{CO}_{2}$ dan menyimpannya dalam bentuk biomassa. Namun, data dan informasi tentang kandungan biomassa dan karbon pada ekosistem karst sampai saat ini informasinya masih langka dan terbatas. Penelitian ini bertujuan untuk mengidentifikasi komposisi jenis dan potensi simpanan karbon vegetasi ekosistem karst di TN Bantimurung Bulusaraung yang mencakup karbon di atas permukaan tanah (above ground biomass).

\section{METODE PENELITIAN}

\section{Lokasi dan Waktu}

Penelitian dilaksanakan pada tipe ekosistem karst di Resort Tondong Tallasa Seksi Pengelolaan Taman Nasional Wilayah I Balocci Taman Nasional Bantimurung Bulusaraung, Kabupaten Pangkep, Provinsi Sulawesi Selatan. Penelitian ini dilaksanakan mulai bulan April 2017 sampai dengan Juni 2017.

\section{Pengumpulan Data}

Pengumpulan data primer meliputi diameter dan tinggi pohon, berat basah dan berat kering tumbuhan bawah, nekromassa, dan serasah untuk dicari nilai biomassa dan karbon tersimpan. Penentuan letak plot contoh pengukuran simpanan karbon dilakukan dengan menggunakan purposive sampling. Bagian-bagian hutan bukit kapur yang dianggap mewakili tersebut antara lain daerah datar, lorong patahan, lereng dengan sedikit batu, lereng dengan banyak batu, dan punggung bukit. Jumlah plot contoh sebanyak 50 plot dengan plot 
contoh masing-masing berukuran $20 \mathrm{~m} \mathrm{x}$ $20 \mathrm{~m}\left(400 \mathrm{~m}^{2}\right)$. Pengukuran biomassa pohon dilakukan dengan cara tidak merusak (nondestructive) dan untuk tumbuhan bawah dengan cara merusak (destructive).

\section{Analisis Data}

Indeks Nilai Penting (INP) digunakan untuk menetapkan komposisi jenis, dan dominansi suatu jenis di suatu tegakan (Soerianegara dan Indrawan, 2002).

Diameter $(\mathrm{d})=\frac{\text { Keliling }}{\pi}$

Luas Bidang Dasar $(\mathrm{LBD})=\frac{1}{4} \pi \mathrm{d}^{2}$

Kerapatan $(\mathrm{K})=$

Jumlah individu suatu jenis

Luas seluruh plot

Kerapatan Relatif $(\mathrm{KR}) \quad=$

$\frac{\text { Kerapatan suatu jenis }}{\text { Kerapatan seluruh jenis }} \times 100 \%$

Frekuensi $(\mathrm{F}) \quad=$

Jumlah plot ditemukan suatu jenis Jumlah seluruh plot

Frekuensi $(\mathrm{FR})=$

$\frac{\text { Frekuensi suatu jenis }}{\text { Frekuensi seluruh jenis }} \times 100 \%$

Dominansi (D) $=\frac{\text { Jumlah LBDS suatu jenis }}{\text { Luas seluruh plot }}$

Dominansi Relatif $(\mathrm{DR})=$

$\frac{\text { Dominansi suatu jenis }}{\text { Dominansi seluruh jenis }} \times 100 \%$

Indeks Nilai Penting $(\mathrm{INP})=\mathrm{KR}+\mathrm{FR}+\mathrm{DR}$
Parameter yang digunakan untuk mengetahui tingkat keanekaragaman jenis adalah Indeks keanekaragaman Shannon Wiener (H') (Ludwig \& Reynold, 1988).

$$
\mathrm{H}^{\prime}=-\sum_{i=1}^{s}\left[\left(\frac{n i}{N}\right) \ln \left(\frac{n i}{N}\right)\right]
$$

Keterangan:

$$
\begin{aligned}
& \mathrm{H}^{\prime}= \text { Indeks Keanekaragaman } \\
& \text { Shannon - Wiener } \\
& \mathrm{s} \quad=\text { Jumlah jenis } \\
& \mathrm{ni}=\text { Kerapatan jenis ke }-\mathrm{i} \\
& \mathrm{N}=\text { Total kerapatan }
\end{aligned}
$$

Menurut Mason (1980), terdapat tiga kriteria dalam analisis indeks keanekaragaman jenis yaitu jika nilai H' $<1$, maka termasuk kedalam kategori rendah, nilai $1<\mathrm{H}^{\prime}<3$, maka termasuk kedalam kategori sedang dan akan dimasukkan kedalam kategori tinggi bila $H^{\prime}>3$.

$$
\mathrm{E}=\frac{H^{t}}{\ln (S)}
$$

Keterangan:

$$
\begin{aligned}
\mathrm{E}= & \text { Indeks kemerataan jenis } \\
\mathrm{H}^{\prime}= & \text { Indeks keanekaragaman } \\
& \text { jenis } \\
\mathrm{S}= & \text { Jumlah jenis } \\
\text { Krebs } & (1985), \text { menyatakan bahwa }
\end{aligned}
$$
Indeks Kemerataan rendah apabila $0<\mathrm{E}<$ 0,5 dan kemerataan tinggi apabila 0,5 < E $<1$. 
Pendugaan biomassa dihitung dimana y adalah nilai per plot dan $\bar{y}$ dengan menggunakan persamaan adalah nilai rata-rata potensi, sedangkan $n$ allometrik $\mathrm{BK}=$ 0,0509.p. $\mathrm{DBH}^{2} . \mathrm{T}$ dan adalah jumlah plot. Sedangkan standard Hairiah dkk (2011), $\mathrm{BK}=0,25 \pi \cdot \rho \cdot \mathrm{H}\left(\mathrm{D}^{2}\right)$.

Hairiah dkk (2011), menjelaskan bahwa terdapat persamaan lain yang dapat digunakan untuk menduga nilai biomassa tumbuhan bawah dan serasah, yaitu sebagai berikut:

Total BK $=\frac{\text { BKe sub contoh }}{\text { BBc sub contoh }} \times$ Total BB

Keterangan :

$\mathrm{BK}=$ Berat kering total.

$\mathrm{BKc}=$ Berat kering contoh.

$\mathrm{BBc}=$ Berat basah contoh

$\mathrm{BB}=$ Berat basah total.

Nilai karbon tersimpan pada masing-masing tipe penutupan lahan dihitung dengan menggunakan faktor konversi karbon yang diacu dalam Lasco et al (2004), yaitu, Karbon tersimpan di hutan primer $=$ biomassa $\times 50 \%$.

Uji statistik terdiri dari penghitungan standard deviation (s), standard error ( $\mathrm{S} \bar{y})$ dan coefficient of variation (CV) (Avery dan Burkhart, dalam Manuri dkk., (2011). Penghitungan standard deviation (s) dilakukan dengan menggunakan persamaan:

$$
\mathrm{S}=\sqrt{\frac{\sum y^{2}-(\Sigma y)^{2} / n}{n-1}}
$$
error ( $\mathrm{S} \bar{y})$ dihitung dengan persamaan:

$$
\mathrm{S}=\sqrt{\frac{s^{2}}{n-1}}
$$

Selanjutnya selang kepercayaan dapat dihitung dengan cara:

Nilai rata-rata $+\mathrm{t} *$ (standard error) atau $\bar{y}+\mathrm{tSy}$ dimana nilai $\mathrm{t}$ digunakan angka 2. Persentase standard error dihitung dengan persamaan:

$$
\mathrm{SE} \%=\frac{\mathrm{tS} \bar{y}}{\bar{y}} * 100
$$

Untuk menghitung variasi antar plot (Coefficient of Variation - CV) dapat menggunakan persamaan:

$$
\mathrm{CV} \%=\frac{\underline{S} \bar{y} * 100}{\bar{y}}
$$

\section{HASIL}

\section{Komposisi Jenis}

Hutan primer datar memiliki jumlah jenis tingkat pohon diameter $>20$ $\mathrm{cm}$ terbanyak yaitu 18 jenis, termasuk dalam 15 famili, sedangkan hutan primer lereng Sedikit batu memiliki jumlah jenis tingkat pohon diameter 5-20 cm terbanyak yaitu 22 jenis, termasuk dalam 17 famili.

Berdasarkan Tabel 1 menyajikan lima nilai INP pada tingkat pohon diameter $>20 \mathrm{~cm}$ yang terdiri dari jenis Syzygium acuminatissima mendominasi di 
hutan primer datar, jenis Kleinhovia molucana mendominasi di hutan primer hospita mendominasi di hutan primer lereng banyak batu dan hutan primer lorong patahan, jenis Pterocymbium punggung bukit.

tinctorium mendominasi di hutan primer

lereng sedikit batu, jenis Duabanga

Tabel 1. Lima nilai indeks nilai penting (INP) tertinggi pada tingkat pohon diameter $>20 \mathrm{~cm}$ berdasarkan karakteristik morfologi ekosistem karst

\begin{tabular}{lccccc}
\hline \hline \multirow{2}{*}{ Jenis (Nama Ilmiah) } & \multicolumn{5}{c}{ Indeks Nilai Penting (\%) } \\
\cline { 2 - 6 } & HPD & HPLP & HPLSB & HPLBB & HPPB \\
\hline \hline Alstonia scholaris & - & 58,75 & 17,55 & - & 42,48 \\
Antiaris toxicaria & - & - & 18,43 & - & - \\
Casearia grewiaefolia & - & - & - & 35,33 & - \\
Dracontomelon dao & 41,80 & - & - & - & - \\
Duabanga molucana & - & - & - & 57,28 & 70,33 \\
Ficus variegata & - & - & 17,64 & - & - \\
Ficus sp.3 & 43,91 & - & - & - & - \\
Ficus sp.4 & - & 16,51 & - & - & - \\
Garuga floribunda & - & - & - & 28,82 & 42,04 \\
Kleinhovia hospita & - & 77,43 & - & - & - \\
Laportea stimulans & 32,94 & 56,66 & 40,44 & - & - \\
Melia azedarach & - & - & - & 40,34 & - \\
Pterocarpus indicus & 14,50 & - & - & - & - \\
Pterocymbium tinctorium & - & - & 49,15 & 55,90 & - \\
Sterculia foetida & - & - & - & - & 44,21 \\
Syzygium acuminatissima & 65,80 & 16,40 & - & - & - \\
Ziziphus angustifolius & - & - & - & - & 40,40 \\
\hline Keterangan & & & & &
\end{tabular}

Keterangan:

HPD $=$ Hutan Primer Datar

HPLP $=$ Hutan Primer Lorong Patahan

HPLSB = Hutan Primer Lereng Sedikit Batu

HPLBB = Hutan Primer Lereng Banyak Batu

$\mathrm{HPPB}=$ Hutan Primer Punggung Bukit

Tabel 2. menyajikan lima nilai INP pada tingkat pohon diameter 5 - 20 yang terdiri dari jenis Dracontomelon dao merupakan jenis yang kerap ditemukan atau dominan. Pada hutan primer lorong patahan, jenis Alstonia scholaris merupakan jenis dominan dengan nilai jenis yang dominan. INP tertinggi. Pada hutan primer lereng sedikit batu, jenis Beilschmiedia gemmiflora jenis yang dominan, sedangkan pada hutan primer lereng banyak batu Garuga floribunda jenis yang dominan dan hutan primer punggung bukit jenis Sterculia foetida merupakan 
Much Syachrir : Analisis Komposisi Jenis dan Potensi Simpanan Karbon pada Ekosistem Karst di Resort Tondong Tallasa Tanaman Nasional Bantimurung Bulusaraung

Tabel 2. Lima nilai indeks nilai penting (INP) tertinggi pada tingkat pohon diameter $5-20 \mathrm{~cm}$ berdasarkan karakteristik morfologi ekosistem karst

\begin{tabular}{|c|c|c|c|c|c|}
\hline \multirow{2}{*}{ Jenis (Nama Ilmiah) } & \multicolumn{5}{|c|}{ Indeks Nilai Penting (\%) } \\
\hline & HSD & HPLP & HPLSB & HPLBB & HPPB \\
\hline Aglaia tomentosa & - & - & 23,64 & - & - \\
\hline Alstonia scholaris & - & 71.73 & - & - & - \\
\hline Beilschmiedia gemmiflora & - & - & 48,30 & - & - \\
\hline Canthium glabrum & 55,82 & - & - & - & - \\
\hline Diospyros sp.2 & - & 38,57 & - & - & - \\
\hline Dracontomelon dao & 78,57 & - & - & - & - \\
\hline Dracaena angustifolia & - & - & - & - & 60,51 \\
\hline Duabanga molucana & - & - & - & 28,55 & 18,65 \\
\hline Erythrina subumbrans & - & - & - & - & 28,17 \\
\hline Ficus sp. 2 & - & - & - & 54,71 & - \\
\hline Garuga floribunda & - & - & - & 74,13 & 20,14 \\
\hline Leea aequata & 34,36 & - & 35,16 & - & - \\
\hline Melia azedarach & 25,05 & - & - & - & - \\
\hline Melicope confusa & - & - & 23,54 & - & - \\
\hline Polyscias nodosa & - & 54,80 & 22,56 & - & - \\
\hline Pometia Pinnata & - & 26,29 & - & - & - \\
\hline Pterocymbium tinctorium & - & - & - & 25,34 & - \\
\hline Psychotria montana & - & 26,22 & - & - & - \\
\hline Sterculia foetida & - & - & - & 35,68 & 78,24 \\
\hline Syzygium acuminatissima & 46,20 & - & - & - & - \\
\hline \multicolumn{6}{|l|}{ Keterangan: } \\
\hline \multicolumn{6}{|c|}{ HPD $=$ Hutan Primer Datar } \\
\hline \multicolumn{6}{|c|}{ HPLP = Hutan Primer Lorong Patahan } \\
\hline \multicolumn{6}{|c|}{ HPLSB $=$ Hutan Primer Lereng Sedikit Batu } \\
\hline \multicolumn{6}{|c|}{ HPLBB $=$ Hutan Primer Lereng Banyak Batu } \\
\hline \multicolumn{6}{|c|}{ HPPB $=$ Hutan Primer Punggung Bukit } \\
\hline
\end{tabular}

Tabel 3. Indeks keanekaragaman dan kemerataan tingkat pohon diameter $>20 \mathrm{~cm}$ dan tingkat pohon diameter 5 - $20 \mathrm{~cm}$ pada plot penelitian berdasarkan karakteristik morfologi Ekosistem Karst

\begin{tabular}{|c|c|c|c|c|}
\hline No. & Karakteristik Morfologi & Indeks & $\begin{array}{c}\text { Pohon } \\
\text { Diameter }> \\
20 \mathrm{~cm} \\
\end{array}$ & $\begin{array}{c}\text { Pohon } \\
\text { Diameter } 5 \text { - } \\
20 \mathrm{~cm} \\
\end{array}$ \\
\hline \multirow[t]{2}{*}{1} & Hutan Primer Datar & $\mathrm{H}^{\prime}$ & 2,43 & 2,07 \\
\hline & & $E^{\prime}$ & 0,84 & 0,90 \\
\hline \multirow[t]{2}{*}{2} & Hutan Primer Lorong Patahan & $\mathrm{H}^{\prime}$ & 2,07 & 2,11 \\
\hline & & $E^{\prime}$ & 0,90 & 0,91 \\
\hline \multirow[t]{2}{*}{3} & Hutan Primer Lereng Sedikit Batu & $\mathrm{H}^{\prime}$ & 2,71 & 2,86 \\
\hline & & $E^{\prime}$ & 0,95 & 0,93 \\
\hline \multirow[t]{2}{*}{4} & Hutan Primer Lereng Banyak Batu & $\mathrm{H}^{\prime}$ & 2,15 & 2,30 \\
\hline & & $E^{\prime}$ & 0,93 & 0,81 \\
\hline \multirow[t]{2}{*}{5} & Hutan Primer Punggung Bukit & $\mathrm{H}^{\prime}$ & 2,01 & 2,38 \\
\hline & & $E^{\prime}$ & 0,97 & 0,84 \\
\hline
\end{tabular}

Keterangan:

$\mathrm{H}^{\prime}=$ Indeks Keanekaragaman $\left(\mathrm{H}^{\prime}<1=\right.$ rendah; $1<\mathrm{H}^{\prime}<3=$ sedang; $\quad \mathrm{H}^{\prime}>3=$ tinggi)

$\mathrm{E}^{\prime}=$ Indeks Kemerataan $(0<\mathrm{E}<0,5=$ rendah; $0,5<\mathrm{E}<1=$ tinggi $)$ 
Tabel 3 menyajikan Nilai indeks sumbangan yang cukup berarti terhadap keanekaragaman tertinggi untuk tingkat total BAP berkisar 11,18-95,49 ton/ha pohon diameter $>20 \mathrm{~cm}$ terdapat pada atau 43,63-84,86\%. Sedangkan pohon plot hutan primer lereng sedikit batu yang berdiameter antara 5-20 cm hanya dengan nilai sebesar 2,71 termasuk dalam berkisar $6,73-15,55$ ton/ha atau 10,90 kategori keanekaragaman jenis sedang. 37,22\%.

Sedangkan, pada plot hutan lainnya dari

Tabel 5 menunjukkan bahwa plot tingkat pohon diameter $>20 \mathrm{~cm}$ berkisar hutan primer datar memiliki total BAP antara 2,01-2,43 termasuk dalam kategori dan simpanan karbon tertinggi keanekaragaman jenis sedang. Nilai dibandingkan BAP dan simpanan karbon indeks keanekaragaman tertinggi untuk pada plot hutan lainnya. Adapun total tingkat pohon diameter $5-20 \mathrm{~cm}$ terdapat BAP pada plot hutan primer datar adalah pada plot hutan primer lereng sedikit batu $112,52 \pm 19,05$ ton/ha, sedangkan total dengan nilai sebesar 2,86 termasuk dalam kategori keanekaragaman jenis sedang. Sedangkan, pada plot hutan lainnya dari tingkat pohon diameter $5-20 \mathrm{~cm}$ berkisar antara 2,07-2,38 termasuk dalam kategori keanekaragaman jenis sedang.

simpanan karbonnya adalah 56,26 \pm 9,52 ton/ha. Biomassa yang diukur dalam penelitian ini adalah biomassa atas permukaan (BAP) atau above ground biomass (AGB) yaitu tingkat pohon diameter $>20 \mathrm{~cm}$, tingkat pohon diameter

Tabel 4 menyajikan bahwa pohon yang berdiameter $>20 \mathrm{~cm}$ memberikan 5 - $20 \mathrm{~cm}$, nekromassa, tumbuhan bawah dan serasah.

Tabel 4. Biomassa tingkat pohon $(\mathrm{P})$ diameter $>20 \mathrm{~cm}$, tingkat pohon diameter $5-20 \mathrm{~cm}$, nekromassa $(\mathrm{N})$, tumbuhan bawah $(\mathrm{TB})$ dan serasah $(\mathrm{S})$ berdasarkan karakteristik morfologi ekosistem karst

\begin{tabular}{|c|c|c|c|c|c|c|}
\hline \multirow[b]{2}{*}{ Karakteristik Morfologi } & \multicolumn{2}{|c|}{$\mathrm{P}($ ton/ha $)$} & \multirow[b]{2}{*}{$\begin{array}{c}\mathrm{N} \\
\text { (ton/ha) }\end{array}$} & \multirow[b]{2}{*}{$\begin{array}{c}\text { TB } \\
\text { (ton/ha) }\end{array}$} & \multicolumn{2}{|c|}{$\mathrm{S}$ (ton/ha) } \\
\hline & $\begin{array}{c}\mathrm{D}>20 \\
\mathrm{~cm}\end{array}$ & $\begin{array}{c}\text { D } 5-20 \\
\text { cm }\end{array}$ & & & Daun & Ranting \\
\hline Hutan Primer Datar & 995,49 & 12,26 & 2,15 & 0,69 & 0,90 & 1,03 \\
\hline Hutan Primer Lorong Patahan & 66,19 & 12,84 & 6,77 & 0,78 & 1,47 & 1,25 \\
\hline Hutan Primer Lereng Sedikit Batu & 68,76 & 15,55 & 16,88 & 0,75 & 1,21 & 1,09 \\
\hline Hutan Primer Lereng Banyak Batu & 13,43 & 11,46 & 2,90 & 1,21 & 0,90 & 0,88 \\
\hline Hutan Primer Punggung Bukit & 11,18 & 6,73 & 0,73 & 2,10 & 0,98 & 0,98 \\
\hline
\end{tabular}


Much Syachrir : Analisis Komposisi Jenis dan Potensi Simpanan Karbon pada Ekosistem Karst di Resort Tondong Tallasa Tanaman Nasional Bantimurung Bulusaraung

Tabel 5. Biomassa di atas permukaan (BAP) dan simpanan karbon berdasarkan karakteristik morfologi ekosistem karst

\begin{tabular}{lcc}
\hline \multicolumn{1}{c}{ Karakteristik Morfologi } & Rerata Total BAP \pm & Rerata Total Simpanan Karbon \pm \\
SE (ton/ha) & SE (ton/ha) \\
\hline \hline Hutan Primer Datar & $112,52 \pm 19,05$ & $56,26 \pm 9,52$ \\
Hutan Primer Lorong Patahan & $89,29 \pm 17,74$ & $44,64 \pm 8,87$ \\
Hutan Primer Lereng Sedikit Batu & $104,23 \pm 19,69$ & $52,12 \pm 9,84$ \\
Hutan Primer Lereng Banyak Batu & $30,78 \pm 6,11$ & $15,39 \pm 3,06$ \\
Hutan Primer Punggung Bukit & $22,70 \pm 4,51$ & $11,35 \pm 2,26$ \\
\hline \hline
\end{tabular}

Keterangan:

$\mathrm{BAP}=$ Biomassa atas permukaan

$\mathrm{SE} \quad=$ Standard Error

Tabel 6. Publikasi simpanan karbon (pohon, tumbuhan bawah, nekromassa dan serasah) untuk lahan kering di Sulawesi

\begin{tabular}{|c|c|c|c|}
\hline No. & Tipe Hutan & Lokasi & $\begin{array}{c}\text { Simpanan Karbon } \\
\text { (ton/ha) }\end{array}$ \\
\hline 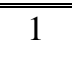 & $\begin{array}{l}\text { Hutan lahan kering dataran } \\
\text { rendah primer }\end{array}$ & Cagar Alam Kalaena $^{1}$ & 77,19 \\
\hline 2 & $\begin{array}{l}\text { Hutan lahan kering dataran } \\
\text { tinggi primer }\end{array}$ & Cagar Alam Faruhumpenai ${ }^{2}$ & 135,20 \\
\hline 3 & $\begin{array}{l}\text { Hutan lahan kering dataran } \\
\text { rendah sekunder }\end{array}$ & $\begin{array}{l}\text { Hutan dataran rendah Lingua, } \\
\text { Taman Nasional Bogani Nani } \\
\text { Wartabone }^{3}\end{array}$ & 274,13 \\
\hline 4 & $\begin{array}{l}\text { Hutan lahan kering dataran } \\
\text { tinggi sekunder }\end{array}$ & $\begin{array}{l}\text { Hutan dataran tinggi Maelang, } \\
\text { Taman Nasional Bogani Nani } \\
\text { Wartabone }^{3}\end{array}$ & 220,79 \\
\hline
\end{tabular}

Pada Tabel 6 menunujukkan hutan lahan kering pada hutan bukit kapur memiliki simpanan karbon berkisar 20,10 $\pm 3,03-63,55 \pm 9,63$ ton/ha lebih rendah dibandingkan dengan hutan lahan kering bukan pada hutan bukit kapur.

\section{Pembahasan}

Berdasarkan hasil analisis vegetasi dapat diketahui Indeks Nilai Penting (INP) jenis tumbuhan tertinggi pada berbagai tingkat pohon di lokasi penelitian, menyajikan lima nilai INP tertinggi pada tingkat pohon diameter $>20$ $\mathrm{cm}$ berdasarkan karakteristik morfologi ekosistem karst

Hutan primer datar memiliki jumlah jenis tingkat pohon diameter $>20 \mathrm{~cm}$ terbanyak yaitu 18 jenis, termasuk dalam 15 famili, sedangkan hutan primer lereng Sedikit batu memiliki jumlah jenis tingkat pohon diameter $5-20 \mathrm{~cm}$ terbanyak yaitu 22 jenis, termasuk dalam 17 famili. Tingginya kadar kalsium dan magnesium, banyaknya variasi topografi, kandungan air permukaan yang relatif sedikit, serta 
lapisan tanah yang umumnya tipis $20 \mathrm{~cm}$ terdapat pada plot hutan primer menyebabkan hanya beberapa jenis lereng sedikit batu dengan nilai sebesar tumbuhan yang mampu hidup dan 2,71 termasuk dalam kategori mendominasi di ekosistem karst keanekaragaman jenis sedang. Sedangkan, (Roemantyo dan Noerdjito, 2006).

Pada tingkat pohon diamater $>20$ pada plot hutan lainnya dari tingkat pohon $\mathrm{cm}$, jenis Syzygium acuminatissima diameter $>20 \mathrm{~cm}$ berkisar antara 2,01 mendominasi di hutan primer datar, jenis Kleinhovia hospita mendominasi di hutan primer lorong patahan, jenis 2,43 termasuk dalam kategori keanekaragaman jenis sedang. Nilai indeks keanekaragaman tertinggi untuk tingkat pohon diameter $5-20 \mathrm{~cm}$ terdapat Pterocymbium tinctorium mendominasi di pada plot hutan primer lereng sedikit batu hutan primer lereng sedikit batu, jenis dengan nilai sebesar 2,86 termasuk dalam Duabanga molucana mendominasi di kategori keanekaragaman jenis sedang. hutan primer lereng banyak batu dan hutan primer punggung bukit. Sedangkan pada tingkat pohon diamater $5-20 \mathrm{~cm}$ hutan primer datar, jenis Dracontomelon dao merupakan jenis yang kerap ditemukan atau dominan. Pada hutan primer lorong patahan, jenis Alstonia scholaris merupakan jenis dominan dengan nilai INP tertinggi. Pada hutan primer lereng sedikit batu, jenis Beilschmiedia gemmiflora jenis yang dominan, sedangkan pada hutan primer lereng banyak batu Garuga floribunda jenis yang dominan dan hutan primer punggung bukit jenis Sterculia foetida merupakan jenis yang dominan.

Nilai indeks keanekaragaman Sedangkan, pada plot hutan lainnya dari tingkat pohon diameter $5-20 \mathrm{~cm}$ berkisar antara 2,07 - 2,38 termasuk dalam kategori keanekaragaman jenis sedang.

Nilai indeks kemerataan pada semua plot penelitian dari tingkat pohon diameter $>20 \mathrm{~cm}$ berkisar antara 0,84-0,97 dan nilai indeks kemerataan dari tingkat pohon diameter 5 - $20 \mathrm{~cm}$ berkisar antara 0,81 0,93. Dari nilai-nilai tersebut dapat dikategorikan bahwa nilai kemerataan pada semua plot penelitian termasuk dalam kategori tinggi.

Tingkat kemerataan jenis pada berbagai plot penelitian dari tingkat pohon diameter $>20$ dan tingkat pohon diameter $5-20 \mathrm{~cm}$ tergolong tinggi $(\mathrm{E}>0,6)$. Nilai tertinggi untuk tingkat pohon diameter > indeks kemerataan jenis akan tergolong 
tinggi atau maksimal apabila kelimpahan individu pada tiap jenis hampir sama (Ludwig \& Reynold 1988). Penambahan jenis pada suatu komunitas, terutama jenis yang memiliki nilai individu yang rendah dapat berpengaruh signifikan terhadap nilai indeks kemerataan jenis (E) (Ludwig \& Reynold, 1988). Nilai indeks kemerataan jenis tertinggi terdapat di plot hutan primer punggung bukit pada tingkat pohon diameter $>20$ dan plot hutan primer lereng sedikit batu pada tingkat pohon diameter $5-20 \mathrm{~cm}$.

Total BAP dan simpanan karbon pada plot hutan primer datar tertinggi dibandingkan pada plot hutan lainnya yaitu $112,52 \pm 19,05$ ton/ha, sedangkan total simpanan karbonnya adalah $56,26 \pm$ 9,52 ton/ha. Sebaran kelas diameter pohon merupakan parameter yang berperan penting dalam menentukan Total BAP dan simpanan karbon di beberapa plot penelitian. Pohon yang berdiameter $>20$ cm memberikan sumbangan yang cukup berarti terhadap total BAP berkisar 11,18 95,49 ton/ha atau 43,63 - 84, $86 \%$. Sedangkan pohon yang berdiameter antara 5 - $20 \mathrm{~cm}$ hanya berkisar 6,73 - 15,55 ton/ha atau 10,90 - 37,22\%. Selain itu, kerapatan kayu jenis-jenis yang mendominasi lokasi penelitian juga mempengaruhi total BAP dan simpanan karbon umumnya terdiri dari jenis Syzygium acuminatissima dan Dracontomelon dao di hutan primer datar, Kleinhovia hospita dan Rita Alstonia scholaris di hutan primer lorong patahan, Pterocymbium tinctorium dan Beilschmiedia gemmiflora di hutan primer lereng sedikit batu, Duabanga molucana dan Garuga floribunda di hutan primer lereng banyak batu, Duabanga molucana dan Sterculia foetida di hutan primer punggung bukit.

Tumbuhan menyerap karbon dari udara dan mengkonversinya menjadi senyawa organik melalui proses fotosintesis. Hasil fotosintesis digunakan untuk pertumbuhan secara vertikal dan horizontal. Semakin besarnya diameter pohon disebabkan oleh penyimpanan biomassa hasil konversi karbon yang semakin bertambah besar seiring dengan semakin banyaknya karbon yang diserap pohon tersebut. Secara umum hutan dengan net growth (pohon-pohon yang sedang berada dalam fase pertumbuhan) mampu menyerap lebih banyak karbon, sedangkan hutan dewasa dengan pertumbuhan yang kecil menahan dan menyimpan persediaan karbon tetapi tidak 
dapat menyerap karbon secara ekstra kemungkinan disebabkan kedalaman (Retnowati, 1998).

Cadangan karbon pada suatu sistem tanah yang relatif dangkal.

Kesalahan standar (standard error) penggunaan lahan dipengaruhi oleh jenis untuk hutan primer datar sebesar 16,93\%, vegetasinya. Suatu sistem penggunaan lahan yang terdiri dari pohon dengan spesies yang mempunyai nilai kerapatan kayu tinggi, biomasanya akan lebih tinggi bila dibandingkan dengan lahan yang mempunyai spesies dengan nilai kerapatan kayu rendah (Hairiah \& Rahayu, 2007).

Berdasarkan penelitian yang telah dipublikasikan. Hutan bukit kapur dicirikan dengan keanekaragaman jenis pohon yang lebih kecil dibandingkan dengan hutan dataran rendah, meskipun jumlah jenis diperkirakan kurang lebih sama, hal ini disebabkan karena tingginya kadar kalsium dalam tanah yang tidak dapat ditahan berbagai pohon (Whitten et al., 1987). Selanjutnya Anwar et al dalam Achmad (2011), menginformasikan bahwa vegetasi hutan bukit kapur mempunyai ciri-ciri: kepadatan pohon yang relatif rendah, luas bidang dasar yang relatif kecil, ketinggian pohon umumnya rendah, banyak pohon dengan diameter kecil, yakni berkisar $10-20 \mathrm{~cm}$, total biomassa rendah, dan tidak terdapat famili maupun jenis yang dominan, hal ini hutan primer lorong patahan sebesar $19,86 \%$, hutan primer lereng sedikit batu sebesar 18,89\%, hutan primer lereng banyak batu sebesar 19,87\% dan hutan primer punggung bukit sebesar 19,88\%. Kesalahan dalam penghitungan biomassa dan karbon hutan terjadi pada saat pengukuran di lapangan dan penggunaan alometrik yang berbeda Selain itu, Laumonier et al (2010), menyatakan bahwa jumlah dan ukuran plot contoh juga memberikan pengaruh terhadap tingkat akurasi penghitungan. Berdasarkan GOFC-GOLD (2010), batasan standard error yang diharapkan dalam pengukuran karbon berkisar antara 0\% sampai $20 \%$. Dengan demikian, standard error pengukuran biomassa untuk hutan bukit kapur sesuai dengan rentang standar yang ditetapkan tersebut.

\section{KESIMPULAN}

Berdasarkan hasil penelitian yang dilakukan maka dapat disimpulkan antara lain:

1. Jenis-jenis yang mendominasi pada ekosistem karst terdiri dari jenis Syzygium acuminatissima dan 
Dracontomelon dao di hutan primer datar, Kleinhovia hospital dan Alstonia scholaris di hutan primer lorong patahan, Pterocymbium tinctorium dan Beilschmiedia gemmiflora di hutan primer lereng sedikit batu, Duabanga molucana dan Garuga floribunda di hutan primer lereng banyak batu, Duabanga molucana dan Sterculia foetida di hutan primer punggung bukit.

2. Rata-rata total simpanan karbon hutan primer datar sebesar $56,26 \pm 9,52$ ton/ha, pada hutan primer lorong patahan sebesar 44,64 $\pm 8,87$ ton/ha, pada hutan primer lereng sedikit batu sebesar 52,12 \pm 9,84 ton/ha, pada hutan primer lereng banyak batu sebesar $15,39 \pm 3,06$ ton/ha, dan pada hutan primer punggung bukit sebesar 11,35 \pm 2,26 ton/ha.

3. Pohon yang berdiameter $>20 \mathrm{~cm}$ memberikan sumbangan yang cukup berarti terhadap total BAP berkisar 11,18 - 95,49 ton/ha atau $43,63-84$, $86 \%$. Sedangkan pohon yang berdiameter antara $5-20 \mathrm{~cm}$ hanya berkisar $6,73-15,55$ ton/ha atau 10,90 $-37,22 \%$.

4. Ekosistem Karst TN Bantimurung Bulusaraung memiliki potensi karbon hutan, sehingga upaya konservasi hutan di daerah tersebut penting dilakukan. Bentuk pengelolaan yang baik terhadap hutan dengan menghindari konversi dan degradasi hutan memberikan peluang yang baik dalam mempertahankan simpanan karbon pada ekosistem karst TN Bantimurung Bulusaraung melalui pengendalian deforestasi, mencegah degradasi dan menerapkan praktek silvikultur yang baik.

\section{DAFTAR PUSTAKA}

Achmad, A. 2006. Keanekaragaman Jenis Tumbuhan Bermanfaat Di Kawasan Karst Maros-Pangkep Sulawesi Selatan. Gunung Sewu Indonesian Cave and Karst Journal 2(1): 17-25.

Achmad A. (2006). Sebaran Jenis Tumbuhan Pada Empat Fasies Batuan Karbonat di Kawasan Karst Maros-Pangkep Sulawesi Selatan.Gunung Sewu Indonesian Cave and Karst Journal2(2): 105112.

Achmad A. (2011). Rahasia Ekosistem Hutan Bukit Kapur.Surabaya : Brilian International.

Center for International Forestry Research. (2009). Apakah itu? Pedoman CIFOR Tentang Hutan, Perubahan Iklim dan REDD. Bogor: CIFOR.

Global Observation of Forest and Land Cover Dynamics. (2010). Reducing greenhouse gas emissions from deforestation and degradation in developing countries: a sourcebook of methods and procedures for monitoring, measuring and 
reporting. GOFC-GOLD Report version COP14-2. GOFC GOLD

Project Office, Natural Resources Canada, Alberta, Canada: vii +203 hlm.

Hairiah K. \& Rahayu S. (2007). Pengukuran 'Karbon Tersimpan' di Berbagai Macam Penggunaan Lahan. Bogor. World Agroforestry Centre - ICRAF, SEA Regional Office, University of Brawijaya, Indonesia.

Hairiah K., Ekadinata A., Sari RR. \& Rahayu S. (2011). Pengukuran Cadangan Karbon dari tingkat lahan ke bentang lahan.Bogor. World Agroforestry Centre ICRAF, SEA Regional Office, University of Brawijaya, Indonesia.

Krebs C.J.(1985). Ecology the Experimental Analysis of Distribution and Abundance.Third Edition. New York.

Lasco RD., Pulhin FB., Roshetko JM. \& Banactila MRN. (2004). LULUCF Climate Change Mitigation Project in the Philippines: a Primer. World Agroforestry Centre.Southeast Asia Regional Research Programme.

Laumonier Y., Edin A., Kanninen M. \& Munandar A.W. (2010). Landscape scale variation in the structure and biomass of the hill dipterocarp forest of Sumatra: Implications for carbon stock assessments. Forest Ecology and Management 259: 505-513.

Ludwig JA. \& Reynold JF. (1988). Statistical Ecology. New York: John Wiley and Sons.

Manuri S., Putra C.A.S. \& SaputraA.D. (2011). Tehnik Pendugaan Cadangan Karbon Hutan.Merang REDD Pilot Project, German International Cooperation - GIZ. Palembang: $\mathrm{x}+91 \mathrm{hlm}$.

Mason C. F. (1980). Ecology.Secon Edition. New York : Longman Inc.

Retnowati E. (1998). Kontribusi Hutan Tanaman Eucalyptus grandis Maiden sebagai Rosot Karbon di Tapanuli Utara. Buletin Penelitian Hutan 611. Pusat Penelitian dan Pengembangan Hutan dan Konservasi Alam. Bogor.

Roemantyo \& Noerdjito M. (2006). Keanekaragaman Flora Kawasan Karst di Indonesia. Maryanto I, Noerdjito M, Rosichon U, editor. Bogor (ID): LIPI Pr.

Soerianegara I. \& Indrawan A. (2002). Ekologi Hutan Indonesia. Bogor: Laboratorium Ekologi Hutan, Fakultas Kehutanan IPB.

Whitten J.A., Mustafa M. \& Henderson G.S. (1987). Ekologi Sulawesi. (Diterjemahkan oleh Gembong Tjittrosoepomo). Gajah Mada University Press. Yokyakarta. 